\title{
UDC 342.725:3.077.92:811:811.161.2
}

HALDETSKA Iryna - PhD in Law, Associate Professor, Professor at the Department of Legal Linguistics, National Academy of Internal Affairs, 1, Solomianska str., Kyiv, 03035, Ukraine (igaldetska@ukr.net)

ORCID: https://orcid.org/0000-0003-3400-4539

STRATULAT Natalia - PhD in Philology, Associate Professor, Professor at the Department of Legal Linguistics, National Academy of Internal Affairs, 1, Solomianska str., Kyiv, 03035, Ukraine (stratulat_natala@ua.fm)

ORCID: https://orcid.org/0000-0001-7738-4311

DOI: https://doi.org/10.24919/2522-4565.2021.45.7

To cite this article: Haldetska, I., Stratulat, N. (2021). Pytannia derzhavnoi ta mizhnarodnoi mov u ploshchyni suchasnoho zakonodavstva [The issue of the state and international languages within the framework ofmodernlegislation]. Problemy humanitarnych nauk: zbirnyk naukovych prats Drohobytskoho derzhavnoho pedahohichnoho universytetu imeni Ivana Franka. Seriia «Filolohiia» - Problems of Humanities. «Philology» Series: a collection of scientific articles of the Drohobych Ivan Franko State Pedagogical University, 45, 70-83. doi: 10.24919/2522-4565.2021.45.7 [in English].

\section{THE ISSUE OF THE STATE AND INTERNATIONAL LANGUAGES WITHIN THE FRAMEWORK OF MODERN LEGISLATION}

Summary. In terms of the development of modern trends in training, represented in modern law, the speech culture of a lawyer plays a leading role (in particular, forms a positive image of the legal community and Ukraine as the state they represent), and issues of its development and perfection become very relevant both during the process of mastering the profession and directly in legal practice, which, in fact, requires detailed study. The importance of researching the outlined issue is due to the modern dimensions of society (the requirements and standards of the lawyer as a specialist), as well as the coverage of these issues in the legal field.

In the current development of the Ukrainian state, the issue of forming a highly developed professional personality of a lawyer is one of the priority tasks in society. The basis of professional literacy of a representative of the legal sphere is language and communication competencies.

Mastering Ukrainian as a state language and English as an international language at the appropriate level contributes to the competitiveness of a specialist in the labor market: a lawyer can be a highly qualified specialist with perfect mastery of both Ukrainian and English. Public inquiries about the speech and professional competencies of a lawyer are reflected in a number of legal acts, the provisions of which highlight aspects of mandatory knowledge of the state and international languages. The higher the level of communicative competencies, the higher the level of professionalism is.

(C) Haldetska Iryna, Stratulat Natalia, 2021 
The legal provisions of the current normative legal documents provided grounds to characterize the requirements of society to a legal specialist in terms of those competencies that are key in the formation of a professional personality. The legal basis is determined by a certain legislative hierarchy: the reflection of public inquiries both in the Basic Law (the Constitution of Ukraine) and in documents of lower legal force than the legal force of the latter. Proposals for the effective implementation of the legislative spectrum under consideration in the educational sphere: increasing the volume of hours in academic disciplines of the cultural and professional direction; introduction of training courses (in Ukrainian and English) aimed at increasing the level of the culture of professional speech; introduction of trainings for participants in the educational process to master the features of professional speech to the curriculum of applicants in the legal specialty.

Key words: Ukrainian language, English language, current legislation, requirements for a specialist, professional qualification, modern standards, educational sphere, legal sphere.

ГАЛДЕЦЬКА Ірина - кандидат юридичних наук, доџент, професор кафедри правничої лінгвістики, Національна академія внутрішніх справ, пл. Солом'янська, 1 , Київ, 03035, Україна (igaldetska@ukr.net)

ORCID: https://orcid.org/0000-0003-3400-4539

СТРАТУЛАТ Наталія - кандидат філологічних наук, дочент, професор кафедри правничої лінгвістики, Національна академія внутрішніх справ, пл. Солом'янська, 1, Київ,03035, Україна (stratulat_natala@ua.fm)

ORCID: https://orcid.org/0000-0001-7738-4311

DOI: https://doi.org/10.24919/2522-4565.2021.45.7

Бібліографічний опис статті: Галдецька, І., Стратулат, Н. (2021). Питання державної та міжнародної мов у площині сучасного законодавства. Проблеми гуманітарних наук: збірник наукових пращь Дрогобиџького державного педагогічного університету імені Івана Франка. Серія «Філологія», 45, 70-83. doi: 10.24919/25224565.2021.45.7.

\section{ПИТАННЯ ДЕРЖАВНОЇ ТА МІЖНАРОДНОЇ МОВ У ПЛОЩИНІ СУЧАСНОГО ЗАКОНОДАВСТВА}

Анотація. В аспекті розвитку сучасних тенденцій щодо професійної підготовки, репрезентованих у сучасному законодавстві, мовленнєва культура юриста відіграє провідну роль (зокрема, формує позитивний імідж представників правової спільноти й України як держави, яку вони представляють), а питання ії розвитку та досконалості набувають неабиякої актуальності як під час процесу опанування фаху, так $i$ безпосередньо у юридичній практиці, щуо, власне, й потребує детального вивчення. Важливість дослідження окресленого питання зумовлена сучасними вимірами суспільства (тими вимогами та стандартами, що висуваються до правника як фахівия), а також висвітленням иих запитів у законодавчо-правовому полі.

В умовах сучасного розвитку Украӥнської держави питання формування високорозвиненої професійної особистості правника є одним із першочергових завдань у суспільстві. В основі професійної грамотності представника юридичної сфери лежать мовно-комунікативні компетентності. 
Опанування українськоїмовияк державної та англійської якміжнародної на відповідному рівні сприяє конкурентоспроможності фахівияя на ринку праці: висококваліфікованим фахівцем юрист може бути за умов досконалого опанування як украӥнської мови, так $і$ англійської. Запити суспільства щзодо мовленнєво-професійних компетентностей правника відображено в низці нормативно-правових актів, у положеннях яких висвітлено аспекти обов 'язкового володіння державною і міжнародною мовами. Чим вищий рівень комунікативних компетентностей, тим вищий рівень професіоналізму.

Правові положення чинних нормативно-правових документів надали підстави охарактеризувати вимоги суспільства до фахівия-юриста в аспекті тих компетентностей, які є ключовими у формуванні професійноӥ особистості. Правове підгрунтя визначено певною законодавчою ієрархією: відображення суспільних запитів як в Основному Законі (Конституиії України), так $i$ в документах нижчої юридичної сили, ніж юридична сила останнього. Пропозиції щуодо ефективної реалізації аналізованого законодавчого спектра в освітній сфері: збільшення обсягу годин із навчальних дисциплін мовно-фахового напряму; введення до навчального плану здобувачів за правовою спеціальністю навчальних курсів (украӥнською $і$ аналійською мовами), спрямованих на підвищення рівня культури професійного мовлення; запровадження тренінгів для учасників освітнього процесу щуодо опанування особливостей професійного мовлення.

Ключові слова: украӥнська мова, англійська мова, чинне законодавство, вимоги до фахівця, професійна кваліфікація, сучасні стандарти, освітня сфера, правова сфера.

Setting the problem and its connection with important scientific or practical tasks. Today, comprehensive systemic reforms in Ukraine confirming its status as a modern democratic state are aimed, along with other tasks, at modernizing the branch of law, where one of the priority issues is the training of a future highly qualified specialist of the legal profession. The needs of society, formed under the influence of the conditions of the present, create new standards for the personality of a legal specialist who is the bearer of the social qualities of the society and meets its needs.

Undoubtedly, in order to provide quality services, a lawyer, along with other professional qualities, must have a high level of professional and communicative culture, which is implemented in speech practice through public speeches, dialogues, documents, interpretation of legal texts etc. After all, legal practitioners constantly work with people from various social groups, various professions and various levels of culture. "Every time they have to find the right tone, words, to justify what is said and express their opinions correctly. Most often, the way a lawyer expresses the opinion depends on how well others are aware of it and how accurately they can give their explanations or testimonies" (Короткова, 2019, с. 142).

The challenges of modern society regarding the formation of professional communicative competence of a lawyer, the development of cultural and linguistic personality of the specialist have a legal basis: regulations of current legislation 
enshrine the relevant provisions on educational language policy taking into account the requirements of society.

Currently, mastering Ukrainian as a state language and English as an international language at the appropriate level contributes to the competitiveness of a legal professional in the labor market, since a lawyer faces the requirements of the country at the national and international levels.

Therefore, in the aspect of the development of modern trends in professional training, presented in modern legislation, the speech culture of a lawyer plays a leading role (in particular, it forms a positive image of representatives of the legal community and Ukraine as the state they represent), and the issue of its development and perfection is of particular relevance both during the process of mastering the specialty, and directly in professional practice, which, in fact, requires further study.

Research analysis. Scientific publications of modern research indicate a significant increase in the interest of researchers in the linguistic, speech and communicative competence of a specialist in the field of jurisprudence. So, Yu. Korotkova (2019), L. Matsko (2007), I. Plotnitska (2008) analyze the features of professional speech, its implementation in modern conditions, and also highlight the theoretical aspects of the concept and structure of the culture of a lawyer's speech; N. Artikutsa (Artikutsa, 2018), N. Marusych (Marusych, 2012) study new ways of language training for future lawyers; O. Yurchuk (Yurchuk, 2017) examines the effectiveness of communication of law enforcement officers in the paradigm of innovation; I. Haldetska (Haldetska, 2018), O. Kovalenko (Kovalenko, 2009), N. Vareshkina (Vareshkina, 2020) cover the issues of mastering a foreign language as a means of communication in professional activities; Y. Baranovska (Baranovska, 2015), S. Tsyhanii (Tsyhanii, 2015) investigate the formation of the professional speech competence of future law enforcement specialists.

The topicality of the research. Despite the fact that the formation and improvement of speech culture of lawyers are presented in the works of many scholars, we consider it appropriate to examine the language-professional aspect as one of the important areas of legal activity, taking into account modern measurements (those requirements and standards for a lawyer as a specialist) within the legislative and legal fields.

The purpose of the article is a comprehensive analysis of speech and professional competence of a lawyer in the legislative and legal aspect. Implementation of the set purpose provides resolving the following tasks: to reveal a role in formation of the professional personality of the lawyer of communicative competence (along with language and speech); to characterize the normative documents of the current legislation regulating modern requirements to the specialist-lawyer concerning knowledge of the Ukrainian and the English languages; to trace the hierarchy of normative legal acts in terms of the analyzed issue (from general to specific, from basic to derivative); to provide proposals for the effective implementation of the legislative spectrum in the field of education. 
The object of the research is the modern legislation of Ukraine. The subject is legal provisions on the proficiency in the state and international languages by specialists in the legal field.

Describing methods applied. The research was carried out on the basis of normative legal acts that reflect the issues of educational language policy in Ukraine, in particular Ukrainian as a state language, as well as English as an international language. The analysis of the studied materials was carried out by using linguistic methods. In particular, comparative analysis was used to identify commonalities and differences between the provisions of legal documents outlining the issues of communicative competence of a lawyer (knowledge of Ukrainian as a state language and English as an international language). In addition, a descriptive analysis was applied in the process of covering the revealed provisions characteristic of a specific normative act on the availability of the necessary level of the Ukrainian and English languages among legal professionals.

The novelty of the research, the theoretical and practical value of the obtained results. For the first time, the issue of the Ukrainian language as a state language and English as an international language through the prism of modern Ukrainian legislation is described and systematized. Specific articles and clauses of the relevant legal statements of current documents are analyzed as an effective regulatory component for the formation of communicative competence. The hierarchical relationship and interdependence of regulatory legal acts regarding the functioning and development of the state and international languages are described. The presented materials can be used when concluding the regulatory framework of the educational process of higher educational institutions (including the development of standards, curricula, educational programs, etc.), as well as in the process of creating educational and methodological support (manuals, guidelines, lecture courses, etc.).

Presentation of the research with substantiation of the obtained results. Given the fact that professional speech reflects the content of the concept of "competence" (language, speech, communication - in the professional aspect), we consider it appropriate to note that the Law of Ukraine "On Higher Education" interprets this lexical unit as "a person's ability to successfully socialize, learn, carry out professional activity that arises on the basis of a dynamic combination of knowledge, skills, abilities, ways of thinking, views, values, other personal qualities" (paragraph 13 of Article 1) (Закон України «Про вищу освіту» 2014).

It would be appropriate to emphasize that since "competencies are primarily the order of society to train its citizens, their list is largely determined by the agreed position of society in a particular country" (Forum osvita.ua) - in our study, this category will be considered in the plane of public demand of the Ukrainian state regarding the language and speech readiness of a lawyer in the plane of its current legislation.

One of the key competencies of a future lawyer is communicative competence, the elements of which are language and speech competence, and with which it directly interacts (while disclosing their content). This is due to the fact that this 
competence is a complex integrative quality of an individual, which characterizes the level of knowledge and skills in the field of communication, sufficient to solve professional problems (Марченко, 2009, с. 184). As a defining professional trait, communicative competence (knowledge of language means and communication situations, mastery of a set of speech skills) allows a lawyer to achieve effectiveness in communication and interaction, correctly compose and understand different texts, adequately use language tools according to specific conditions and tasks of communication (Левітан, 2005, с. 76).

In addition, since a lawyer as a specialist deals with different segments of the population (the legal profession has a high degree of socialization); the success in his professional activity depends on how he will be able to reveal and convey the meaning of what has been said (Стратулат, 2020, c. 253).

It is clear that knowledge of the language, proficiency in and use of the language are those competencies that are implemented in professional activity of a lawyer, are interdependent, complementary, and can function only if they are identi$\mathrm{cal}$. The formation of language competence (acquiring the skills to speak and write correctly, the ability to express one's opinion accurately) further contributes to the effectiveness of speech competence (the ability to apply theoretical knowledge in practice) (Сукаленко, 2014, с. 94). And speech competence, in turn, becomes the basis for effective communication (communicative competence).

Undoubtedly, these competencies (communicative, linguistic and speech), on the one hand, are the basis for mastering, in fact, professional (subject) awareness of a lawyer as a specialist, and also occupy an important place in the formation of highly qualified expert, professional, multi-vector personality able to effectively solve professional problems. After all, in modern society, "the formation of polyprofessionalism, which replaces the monoprofessionalism of professions, occurs as a continuous process of an individual search for the meaning of life and professional self-determination, focused on choosing specialization in future professional activity as a lawyer-practitioner" (Чорнобай, 2015, с. 246).

On the other hand, a lawyer by occupation should not only be professionally erudite, i.e. "to act according to the law, but also to explain, prove, convince. Therefore, a lawyer must be a professional communicator" (Введенская, 2006, с. 9). То be able to influence the listener by means of words, to formulate an opinion in such a way as to convey the meaning of legal concepts, to interpret the relevant provisions are the practical tasks of a lawyer.

Since the modern needs of society are focused on a highly developed, comprehensively competent professional personality capable of meeting the needs of the country at the state and international levels, in our study we will consider the issue of the communicative competence of a specialist in a two-dimensional space: within the framework the Ukrainian language as a state language and English as an international one. The issue of mastering each of these languages by a specialist has its own legitimate grounds: expanding the prospects for establishing Ukraine in its identity, independence, on the one hand, as well as entering the international arena, 
and presenting our country as a strong law-based state at the world level through intercultural communication and international legal communication, - on the other.

The formation of professional communicative competence (in particular, language and speech) among future lawyers, the development of the cultural and linguistic personality of a specialist that is due to the challenge of modern Ukrainian society, have a legislative and legal basis: the request of society is reflected in regulatory legal acts, which, in fact, falls into the legal field of current legislation.

The legal framework governing the development and functioning of languages in the state (in particular, to meet the needs of society), and also reflects the rights and obligations of knowing the state and international languages in the aspect of the formation of communicative competencies of specialists in the legal field, is represented by a wide range of documents from the Basic Law of regulatory legal acts of the educational sphere. We will analyze the specific provisions of the issue under study on the material of the relevant legal documents.

Thus, the Constitution of Ukraine (Article 10 of Section 1) regulates that "The state language in Ukraine is the Ukrainian language. The state ensures the comprehensive development and functioning of the Ukrainian language in all spheres of public life throughout Ukraine. The state promotes the study of languages of international communication. The use of languages in Ukraine is guaranteed by the Constitution of Ukraine and is determined by law" (Конституція України, 1996).

So, legally, the Ukrainian language as the state language is a priority in Ukraine, and "the all-round development and functioning» of the state language includes mastering it (including during the educational process) at the appropriate level. Along with this, the state "promotes the study of languages of international communication" (which includes English), thus introducing an educational language policy for the development of the Ukrainian society, expanding the range of implementation of intercultural and international opportunities.

The Law of Ukraine "On Ensuring the Functioning of the Ukrainian Language as the State Language" (Закон України «Про забезпечення функціонування української мови як державної», 2019) is also noteworthy in terms of the research issue.

Thus, paragraph 1. Art. 6 of this Law states: "Every citizen of Ukraine is obliged to speak the state language", and paragraph 2 of the same article states that the state "... provides every citizen of Ukraine with opportunities to master the state language..." through a system of educational institutions, including higher educational institutions. In addition, paragraph 1. Art. 9 in the list of persons "who are obliged to speak the state language and use it in the performance of official duties", indicates those whose professional activities are related to the legal sphere. Also, Art. 14 "Application of the state language in court proceedings" and Art. 16 "The use of the state language in law enforcement agencies, intelligence agencies, and the state bodies of special purpose with law enforcement functions" certify the requirements for legal professions. And, of course, the key article on the formation of communicative competence (also language and speech) is Art. 21 "State language 
in the field of education", which states that "the language of the educational process in educational institutions is the state language", as well as that the state guarantees every citizen of Ukraine the right to education (paragraph 1); "educational institutions provide compulsory study of the state language, in particular... professional before higher and higher education, to the extent that allows to carry out professional activities in the selected field using the state language" (p. 2); "The state promotes the study of languages of international communication, especially English, in public and municipal educational institutions" (p. 4) "In educational institutions in accordance with the educational program, one or more subjects may be taught in two or more languages - the state language, the English language, in other official languages of the European Union" (paragraph 5).

As you can see, in the described normative legal act, a prominent place is given to the issue of mastering the state language (in particular, with the aim of further effective implementation of speech professional activity). In addition, this Law (given the modern dimensions of the professional characteristics of the specialist) is also important in the context of language policy "the study of languages of international communication, especially English".

Based on the normative acts of the highest legal force (described above) legal documents in the field of education represent an outlined issue from the point of view of ensuring high-quality training of lawyers during the educational process. So, we will turn to the content of the Law of Ukraine "On Education" (Закон України «Про освіту»).

In a number of principles of state policy in the field of education and the principles of educational activities (Art. 6), we single out such as "diversity of education"; "integration with the labor market"; "inseparable connection with world and national history, culture, national traditions"; "integration into the international educational and scientific space"; "education of patriotism, respect for the cultural values of the Ukrainian people, its historical and cultural heritage and traditions". In fact, these components are a confirmation of the basic provisions of modernization of education through perfect mastery of the state language, as well as English, focusing on further professional practice. In addition, Art. 7 "Language of Education" (p. 1,2) defines the issues of educational activities in the state language (according to the above-mentioned Law of Ukraine "On ensuring the functioning of the Ukrainian language as a state language" clauses 1,2 , Article 21), and clauses 3.4 - on the study of languages of international communication, in particular English (in accordance with the said Law, clauses 3, 4, Art. 21).

In addition, paragraph 1 of Art. 17 "Higher education" states that the goal of higher education is to obtain a person of a high level of scientific and / or "professional and general competence necessary for activities in a certain specialty or in a certain field of knowledge". Certainly, professional and general competence are directly acquired with perfect linguistic awareness, on the one hand, and on the other - speech- communicative competence, in fact, is included in the field of certain competence. 
For its part, the Law of Ukraine "On Higher Education" covers the corresponding levels for the training of specialists with higher education (clause 1 of Article 5), noting that "The educational and scientific level of higher education provides for the acquisition by a person of theoretical knowledge, abilities, skills and other competencies sufficient for the development of new ideas, the solution of complex problems in the field of professional and / or experimental and innovative activities...". A number of competences, certainly, include those related to the linguistic, speech and communicative training of a future specialist to ensure effective professional activity in the future. It is also determined (clause 1 of Article 9) a prerequisite for the implementation of educational act: "Educational programs that provide for the award of professional qualifications must ensure compliance with the requirements of relevant professional standards, unless otherwise provided by law". These relevant professional standards disclose the content of the requirements for the development of professional qualifications; concretize, directly, the requests for a particular profession.

In addition, the Cabinet of Ministers of Ukraine (Resolution of the Cabinet of Ministers of Ukraine "On approval of the National Qualifications Framework") provides a description of qualification levels, including a description of the bachelor's level, outlining the communication requirements of this level: "reporting to specialists and non-specialists information, ideas, problems, solutions, personal experience and argumentation; collection, interpretation and application of communication data on professional issues, including in a foreign language, orally and in writing” (Постанова Кабінету Міністрів України № 1341, 2011). As we can see, "communication of information, ideas", etc. "communication... orally and in writing" means mastering the skills of literacy and communication in the state language in the professional sphere (because, as noted above, professional activities are implemented through the functioning of the Ukrainian language). It should be noted that knowledge of a foreign language is a mandatory component: "communication on professional issues, including a foreign language".

We will turn to the above-mentioned professional standards enshrined in the Order of the Ministry of Education and Science of Ukraine "On approval of the standard of higher education in the specialty 081 "Law" for the first (bachelor's) level” (Наказ Міністерства освіти та науки України «Про затвердження стандарту вищої освіти за спеціальністю 081 «Право», 2018).

We will consider those that characterize the degree of higher education of the bachelor, in particular the field of knowledge 081 "Law" specialty 081 "Law". Thus, in the section "General competencies" we find the relevant items (GC - general competencies 4, 5), which reflect the topic of our study: "GC 4. The ability to communicate in the state language both orally and in writing; GC 5. The ability to communicate in a foreign language". As you can see, in accordance with the requirements of this document, communication in the state and foreign languages is a necessary condition for legal qualification. In addition to general competencies, which contain information on language and communication training of lawyers, the relevant information can be found in the section "Special (professional, subject) competencies". 
For example, in items 12,14, 16 (SC - special competencies) "SC12. The ability to analyze legal problems, to form and substantiate legal positions; SC14. The ability to advise on legal issues, in particular, possible ways to protect the rights and interests of clients, in accordance with the requirements of professional ethics, proper compliance with the rules on non-disclosure of personal data and confidential information; SC16. The ability to logical, critical and systematic analysis of documents, understanding of their legal nature and meaning" clearly demonstrates the content of competencies that are implemented through the available language and speech knowledge, skills and abilities.

Obviously, taking into account the current legislation, the state sets the conditions for compulsory knowledge of languages, both state - Ukrainian, and international - English (in oral and written forms) for the participants of legal communication (primarily the lawyer himself). The outlined peculiar sequence of normative documents, which brightly covers the language issue in the aspect of the activity of a legal specialist, does not call into question this statement: the Constitution of Ukraine $\rightarrow$ the Law of Ukraine "On ensuring the functioning of the Ukrainian language as a state language" $\rightarrow$ the Law of Ukraine "On Education" $\rightarrow$ the Law of Ukraine "On Higher Education" $\rightarrow$ Resolution of the Cabinet of Ministers of Ukraine "On Approval of the National Qualifications Framework" $\rightarrow$ Order of the Ministry of Education and Science of Ukraine "On Approval of the Standard of Higher Education in Specialty 081 "Law" for the First (Bachelor's) Level".

Conclusions and proposals. The study gives grounds to assert that a prominent place in the professional activity of each lawyer belongs to these competencies that reflect knowledge of the language, language proficiency and use of the language. For their part, they play a key role in shaping the professional personality of a lawyer, making him a highly-qualified specialist. Mastering the Ukrainian language as the state language and English as the international language at the appropriate level contributes today to the competitiveness of the specialist in the labor market. The analysis of normative documents provided an opportunity to characterize the requirements (enshrined in current legislation) for a specialist in the legal field at the present stage regarding the specified competencies in Ukrainian and English. The legal basis is defined by a certain legislative hierarchy: it is reflected both in the Basic Law (the Constitution of Ukraine) and in documents of lower legal force than the legal force of the latter.

In view of the study, we provide the following proposals for the effective implementation of the legal spectrum in the field of education: to increase the number of hours in the disciplines "Ukrainian for Professional Purposes" and "English for Professional Purposes"; it is obligatory to include training courses in "Rhetoric", "Culture of professional speech", "Effectiveness of professional communication" in the curriculum of bachelors in the specialty 081 "Law" which will be conducted in both Ukrainian and English; to introduce trainings for participants of the educational process (both teachers and applicants) "Features of professional speech". 


\section{BIBLIOGRAPHY}

Артикуца Н.В. Мова права та їі вивчення студентами юридичних спеціальностей у вищих навчальних закладах України. Культура народов Причерноморья. 2004. № 49. Т. 2. С. 155-157.

Барановська Л.В., Циганій С.О. Культура мови як складова культури професійно правового спілкування працівників юридичної галузі. Вісник Національного авіаційного університету. Серія «Педагогіка. Психологія». 2015. № 6. С. 23-25.

Богуш А.М. Витоки мовленнєвого розвитку дітей дошкільного віку: програма та методичні рекомендації. Київ : ІЗМН, 1997. 112 с.

Варешкина Н. Методические аспекты формирование эффективного коммуникатора как средства поддержания должного уровня мотивации студентов при обучении иностранному языку а гуманитарном вузе. Актуальні питання гуманітарних наук. Серія «Мовознавство». 2020. № 30. Т. 3. С. 246-253.

Введенская Л.А., Павлова Л.Г. Риторика для юристов : учебное пособие. Ростов-наДону : Феникс, 2006. 576 с.

Закон України «Про вищу освіту» № 1556-VII від 01 липня 2014 р. (редакція від 25.09.2020). URL: https://zakon.rada.gov.ua/laws/show/1556-18\#Text (дата звернення: 02.02.2021).

Закон України «Про забезпечення функиіонування української мови як державної» від 25 квітня 2019 р. № 2704-VIII (редакція від 11.09.2020). URL: https://zakon.rada. gov.ua/laws/show/2704-19\#Text (дата звернення: 02.02.2021).

Закон України «Про освіту» від 5 вересня 2017 р. № 2145-VIII (редакція від 01.01.2021). URL: https://zakon.rada.gov.ua/laws/show/2145-19\#Text (дата звернення: 02.02.2021).

Коваленко О.Я. Ключ до відкриття світу, або Практичне спрямування іншомовної освіти. Іноземні мови в навчальних закладах. 2009. № 4. С. 6-12.

Конституичія України від 11 березня 1996 р. (редакція від 01.01.2020). URL: https:// zakon.rada.gov.ua/laws/show/254\%D0\%BA/96-\%D0\%B2\%D1\%80\#Text (дата звернення: 02.02.2021).

Короткова Ю.М. Поняття структури і культури мовлення юриста. Правовий часопис Донбасу. 2019. № 2. С. 148-149.

Левитан К.М. Компетентносный подход в юридическом образовании. Aктуальные проблемы современного права и юридического образования : материалы научно-практической конференции. Екатеринбург, 2005. С. 76-79.

Марусич Н.Ю. Українська мова за професійним спрямуванням. Культура професійного мовлення : навчальний посібник. Київ, 2012. 236 с.

Марченко Ю.Г. Комунікативна компетентність як одна 3 ключових компетентностей майбутнього юриста. Наукові пращі. Серія «Педагогіка, психологія і сочіологія». 2009. № 5/1(155). С. 183-187.

Мацько Л.І., Кравець Л.В. Культура української фахової мови : навчальний посібник. Київ : Академія, 2007. С. 6-7.

Наказ Міністерства освіти та науки Украӥни «Про затвердження стандарту вищої освіти за спеціальністю 081 «Право»для першого (бакалаврського) рівня» № 1379 від 12 грудня 2018 p. URL: https://mon.gov.ua/storage/app/media/vishchaosvita/zatverdzeni\%20standarty/12/21/081-pravo-bakalavr.pdf.

Плотницька І.М. Ділова українська мова : навчальний посібник. Київ : Центр учбової літератури, 2008. 256 с. 
Постанова Кабінету Міністрів Украӥни «Про затвердження Національної рамки кваліфікаиій» від 23 листопада 2011 р. № 1341 (редакція від 02.07.2020). URL: https://zakon.rada.gov.ua/laws/show/1341-2011-\%D0\%BF\#Text (дата звернення: 02.02.2021).

Стратулат Н.В. Питання лексичної норми в мовленнєво-професійній діяльності. Актуальні питання гуманітарних наук. Серія «Мовознавство». 2020. Вип. 31. T. 2. C. 251-256.

Сукаленко Т.М. Формування культури мовлення у сфері професійної діяльності економіста. Наукові записки Бердянського державного педагогічного універсиmету. 2014. Вип. IV. С. 93-97.

Форум. Сучасна освіта. URL: http://osvita.ua/school/method/2340/ (дата звернення: 02.02.2021).

Чорнобай О.Л. Розвиток комунікативної компетентності юриста на етапах його професійного становлення. Вісник Наџіонального університету «Львівська політехніка». 2015. С. 241-246.

Юрчук О.Ф. Комунікативна компетентність правника в парадигмі інновацій. Українська мова в юриспрудениї: стан, проблеми, перспективи : матеріали XIII Bceукр. наук.-практ. конф., м. Київ, 2018 р. : у 2-х ч. Київ : Нац. акад. внутр. справ, 2017. Ч. 1. C. 31-33.

Haldetska I.O., Vasylenko O.V. Learning professional foreign languages as an integral part of the policemen raining. Інноваційні технологї у контексті іншомовної підготовки фахівия : матеріали IV Міжнар. наук-практ конф. Полтава, 2018. C. 26-29.

\section{REFERENCES}

Artykutsa, N.V. (2004). Mova prava ta yii vyvchennia studentamy yurydychnykh spetsialnostei $\mathrm{u}$ vyshchykh navchalnykh zakladakh Ukrainy [The language of law and its study by students of law specialties in higher educational institutions of Ukraine]. Kultura narodov Prychernomoria - Culture of the people of the Black Sea region, (Issue 49, Vol. 2), (pp. 155-157) [in Ukrainian].

Baranovska, L.V., Tsyhanii S.O. (2015). Kultura movy yak skladova kultury profesiinopravovoho spilkuvannia pratsivnykiv yurydychnoi haluzi [Language culture as a component of the culture of professional legal communication of legal professionals]. Visnyk Natsionalnoho aviatsiinoho universytetu. Seriia: Pedahohika, Psykholohiia - Proceedings of the National Aviation University. Series: Pedagogy. Psychology, (Issue 6), (pp. 23-25) [in Ukrainian]

Bohush, A.M. (1997). Vytoky movlennievoho rozvytku ditei doshkilnoho viku [The origins of speech development in preschool children: program and methodical recommendations], Kyiv: IZMN, (p. 112) [in Ukrainian].

Vareshkina, N. (2020). Metodicheskiie aspekty formirovaniia éffektivnoho kommunikatora kak sredstva podderzhaniia dolzhnoho urovnia motivatsii studentov pri obuchenii inostrannomu yazyku v humanytarnom vuze [Methodological aspects of forming an effective communicator as a means of maintaining the appropriate level of motivation of students while learning a foreign language at a humanities university]. Aktualni pytannia humanitarnykh nauk: mizhvuzivskyi zbirnyk naukovykh prats molodykh vchenykh Drohobytskoho derzhavnoho pedahohichnoho universytetu imeni Ivana Franka, Seriia "Movoznavstvo» - Current issues of the humanities, Drohobych, (Issue 30, Vol. 3), (pp. 246-253) [in Ukrainian]. 
Vvedenskaia, L.A., Pavlova, L.H. (2006). Ritorika dlia yuristov [Rhetoric for lawyers]: Uchebnoie posobiie - Tutorial. Rostov-on-Don: Feniks. (p. 576) [in Russian].

Zakon Ukrainy «Pro vyshchu osvitu» [Law of Ukraine “On Higher Education”] № 1556-VII vid 01 lypnia 2014 r. (redaktsiia vid 25.09.2020). Retrieved February 2, 2021, from https://zakon.rada.gov.ua/laws/show/1556-18\#Text [in Ukrainian].

Zakon Ukrainy «Pro zabezpechennia funktsionuvannia ukrainskoi movy yak derzhavnoi» [Law of Ukraine "On ensuring the functioning of the Ukrainian language as the state language"] vid 25 kvitnia 2019 r. № 2704-VIII (redaktsiia vid 11.09.2020) Retrieved February 2, 2021, from https://zakon.rada.gov.ua/laws/show/2704-19\#Text [in Ukrainian].

Zakon Ukrainy "Pro osvitu» [Law of Ukraine "On Education"] vid 5 veresnia 2017 r. № 2145-VIII (redaktsiia vid 01.01.2021). Retrieved February 2, 2021, from https:// zakon.rada.gov.ua/laws/show/2145-19\# [in Ukrainian].

Kovalenko, O.Ya. (2009). Kliuch do vidkryttia svitu, abo praktychne spriamuvannia inshomovnoi osvity [The key to discovering the world, or the practical direction of foreign language education]. Inozemni movy $v$ navchalnykh zakladakh - Foreign languages in educational institutions (Issue 4), (pp. 6-12) [in Ukrainian].

Konstytutsiia Ukrainy [Constitution of Ukraine] vid 11 bereznia 1996 r. (redaktsiia vid 01.01.2020) Retrieved February 2, 2021, from https://zakon.rada.gov.ua/laws/ show/254\%D0\%BA/96-\%D0\%B2\%D1\%80\#Text [in Ukrainian].

Korotkova, Yu.M. (2019). Poniattia struktury i kultury movlennia yurysta [The concept of structure and culture of speech of a lawyer]. Pravovyi chasopys Donbasu-Legal magazine of Donbass, (Issue 2), (pp. 148-149) [in Ukrainian].

Levitan, K.M. (2005). Kompetentnosnyi podkhod V yuridicheskom obrazovanii [Competence approach in legal education]. Aktualnyie problemy sovremennoho prava $i$ yuridicheskoho obrazovaniia - Actual problems of modern law and legal education Materialy nauchno-prakticheskoi konferentsyi. Ekaterinburh (pp. 76-79) [in Russian].

Marusych, N.Yu. (2012). Ukrainska mova za profesiinym spriamuvanniam [Ukrainian language for professional purposes]. Kultura profesiinoho movlennia. Kyiv. (p. 236) [in Ukrainian].

Marchenko, Yu.H. (2009). Komunikatyvna kompetentnist yak odna z kliuchovykh kompetentnostei maibutnoho yurysta [Communicative competence as one of the key competencies of a future lawyer]. Naukovi pratsi. Seriia: Pedahohika, psykholohiia $i$ sotsiolohiia - Scientific works. Series: Pedagogy, psychology and sociology. (Issue 5/1 (155)), (pp.183-187) [in Ukrainian].

Matsko L.I., Kravets L.V. (2007). Kultura ukrainskoi fakhovoi movy: navch. posibn. [Culture of the Ukrainian professional language: textbook. Manual] (p. 6-7) Kyiv: Vydavnychyi tsentr «Akademiia» [in Ukrainian].

Nakaz Ministerstva osvity ta nauky Ukrainy «Pro zatverdzhennia standartu vyshchoi osvity za spetsialnistiu 081 «Pravo» dlia pershoho (bakalavrskoho) rivnia» [Order of the Ministry of Education and Science of Ukraine "On approval of the standard of higher education in the specialty 081"Law” for the first (bachelor's) level” № 1379] vid 12 hrudnia 2018 roku. Retrieved February 2, 2021, from https://mon.gov.ua/storage/ app/media/vishcha-osvita/zatverdzeni\%20standarty/12/21/081-pravo-bakalavr.pdf. [in Ukrainian]. 
Plotnytska, I.M. (2008). Dilova ukrainska mova [Business Ukrainian language]. (p. 256). Kyiv: Tsentr uchbovoi literatury [in Ukrainian].

Postanova Kabinetu Ministriv Ukrainy «Pro zatverdzhennia Natsionalnoi ramky kvalifikatsii» (Resolution of the Cabinet of Ministers of Ukraine "On approval of the National Qualifications Framework”)] vid 23 lystopada 2011 roku, № 1341 (redaktsiia vid 02.07.2020) Retrieved February 2, 2021, from https://zakon.rada.gov. ua/laws/show/1341-2011-\%D0\%BF\#Text [in Ukrainian].

Stratulat, N.V. (2020). Pytannia leksychnoi normy v movlennievo-profesiinii diialnosti. Aktualni pytannia humanitarnykh nauk: mizhvuzivskyi zbirnyk naukovykh prats' [Questions of lexical norm in speech-professional activity. Current issues of the humanities]: interuniversity molodykh vchenykh Drohobytskoho derzhavnoho pedahohichnoho universytetu imeni Ivana Franka, Seriia «Movoznavstvo», Drohobych,. (Issue 31, Vol.2), (pp. 251-256) [in Ukrainian].

Sukalenko, T.M. (2014). Formuvannia kultury movlennia u sferi profesiinoi diialnosti ekonomista [Formation of speech culture in the field of professional activity of an economist]. Naukovi zapysky Berdianskoho derzhavnoho pedahohichnoho universytetu - Scientific notes of Berdyansk State Pedagogical University, (Issue IV), (pp. 93-97) [in Ukrainian].

Forum. Suchasna osvita [Forum. Modern education]. Retrieved February 2, 2021, from http://osvita.ua/school/method/2340/ [in Ukrainian].

Chornobai, O.L. (2015). Rozvytok komunikatyvnoi kompetentnosti yurysta na etapakh yoho profesiinoho stanovlennia [Development of communicative competence of a lawyer at the stages of his professional development]. Visnyk Natsionalnoho universytetu "Lvivska politekhnika" - Proceedings of the National University "Lviv Polytechnic" (pp. 241-246) [in Ukrainian].

Yurchuk, O.F. (2017). Komunikatyvna kompetentnist pravnyka v paradyhmi innovatsii. Ukrainska mova v yurysprudentsii: stan, problemy, perspektyvy [Ukrainian language in jurisprudence: state, problems, prospects]. Kyiv: Nats. akad. vnutr. sprav (pp. 31-33) [in Ukrainian].

Haldetska I.H., Vasylenko O.V. (2018). Learning professional foreign languages as an integral part of the policemen training. Innovatsiini tekhnolohii u konteksti inshomovnoi pidhotovky fakhivtsia - Innovative technologies in the context of foreign language training (pp. 26-29) [in English]. 